\title{
Rajoja riittää ylitettäväksi
}

Hanna Toiviainen \& Hannu Hänninen (toim.). Rajanylitykset työssä. Yhteistoiminnan ja oppimisen uudet mahdollisuudet. 2006. Jyväskylä: PS-kustannus. 243 sivua.

$\mathrm{V}_{\mathrm{i}}$ iimeaikaiset muutokset työelämässä ovat nostaneet esille uusia ja todellisia haasteita työssä oppimiselle. Verkottuminen on päivän sana, ja on lienee turvallista sanoa, että miltei minkälaisessa tahansa työssä se on jo keskeinen osa työn tekemistä. Tällainen verkottuminen on johtanut väistämättä myös muutoksiin asiantuntijuuden käsittämisessä. Tätä muutosta ja sen vaikutuksia työssä tapahtuvan oppimisentutkimukselle tarkastellaan Rajanylitykset työssä -teoksessa.

Tamperelainen Jaana Parviainen $^{1}$ on kehittänyt tutkijakollegoidensa kanssa käsitettä "kollektiivinen asiantuntijuus" kuvatakseen muutosta, jossa yksilöasiantuntijuuden korvaa yhdessä jaettu ja tuotettu eräänlainen organisatorinen asiantuntijuus. Olen yhdessä Juha Suorannan kanssa tarkastellut tällaisen asiantuntijuuden asettamia haasteita kriittisen asiantuntijakoulutuksen tasolla artikkelissa "Critical Pedagogy as a Collective Social Expertice”"2. Nyt käsillä oleva teos avaa myös tärkeitä näkökulmia tähän asiantuntijakoulutuksen uudistustyöhön.

Rajanylitykset työssä kysyy työssä oppimisen tasolla muun muassa, miksi rajat ja niiden ylittäminen on noussut ajankohtaiseksi tutkimusteemaksi. Jos ammatillisten rajojen ylittäminen on tullut keskeiseksi työskentelyn muodoksi, johtaako tämä monipuolinen yhteistyö rajojen hälvenemiseen vai mahdollistaako se päinvastoin juuri näiden samaisten rajojen entistä voimakkaampaa selvärajaistumista. Jokainen erilaisissa asiantuntijaorganisaatioissa työskentelevä löytää kirjasta monia teemoja, jotka ovat hedelmällisiä lähtökohtia omaa työtä koskevalle pohdinnalle.

Kirjan tutkimuksellinen aineisto on kerätty Suomen Akatemian rahoittamassa tutkimushankkeessa Life as Learning (2002-2006). Kirjan alussa on tiivis kuvaus hankkeesta ja sen tuottamista julkaisuista ja konferensseista. Nämä kuvaukset ovat omiaan luomaan vaikutelmaa, että kirja on tutkimushankkeen loppuraportti. Se ei mielestäni tee hyvää kirjalle, josta kuitenkin on selvästi pyritty tekemään jotain muuta kuin pelkkä raportti. Muutoinkin kirjan typograafinen ilme on kovin sekava ja tuntuu kiireessä tehdyltä. Kirjassa on lukuisia taittoon liittyviä teknisiä puutteita (mm. takakannessa tavutetusta tekstistä puuttuvat tavuviivat!). Nämä tekniset puutteet eivät millään tavoin liity sisällöllisiin seikkoihin.

Toimittajat painottavat sitä, että monin erilaisin tutkimuksellisin ottein toteutetussa hankkeesta voitiin paikantaa yhteinen jaettu ongelmakenttä, joka on kirjan kohteena. Oppiviin organisaatioihin liittyi keskeisesti rajojen ylittäminen ja yhteistoiminnallisuus. Kirjassa on yhdeksän lukua, joista ensimmäinen on yleinen johdattelu kirjan teemaan ja viimeinen on tiivis yhteenveto luku. Kirja on rakenteellisesti selkeä ja jokaiseen lukuun toimittajat ovat kirjoittaneet yhden sivun mittaisen tiivistelmän. Tällainen ratkaisu lisää kirjan käyttökelposuutta muun muassa oppikirjana.

\section{Työ muuttunut vuoro- vaikutuksellisemmaksi}

Hanna Toiviainen ja Hannu Hänninen tarkastelevat artikkelissaan "Työn rajanylitykset oppimisen ja tutkimuksen haasteena” välttämättömyyttä laajentaa teoreettisia ja tutkimuksellisia näkökulmia työelämän muutosten seurauksena. He tulkitsevat työelämän muutokset osana laajempia yhteiskunnallisia ja teknologisia muutoksia, jotka ovat vaatineen sekä mahdollistaneet työn muuttumista entistä enemmän yhteistyöhön ja vuorovaikutukseen perustuvaksi. Nämä muutokset ovat madaltaneet ja rikkoneet työorganisaatioiden rajoja. Hierarkkisuutta on pyritty systemaattisesti purkamaan sekä tekemään mahdolliset rajat eri organisaatiotasojen välillä näkyviksi. Juuri tämän taloudellis-teknisen kokonaisyhteiskunnallisen muutoksen Toiviainen ja Hänninen näkevät yhteiskuntatieteellisen ja kasvatustieteellisen tutkimuksen nykyhaasteena.

\section{Tutkimuksen ottanut}

\section{haasteen vastaan}

Tähän haasteeseen on yhteiskuntatieteissä pyritty vastaamaan verkostoteorioilla, käytäntöyhteisöjä koskevalla tutkimuksella ja uudenlaisten tiedon tuotannon tapojen tutkimuksella. Näitä kaikkia tutkimuksellisia 
suuntauksia tarkastellaan kirjan artikkeleissa kattavasti.

Kirjassa pääfokus kuitenkin asetetaan oppimiseen: "Vaikka työelämän muutokset, yhteistyö ja rajojen ylittäminen ovat olleet tutkimuksen kiinnostuksen kohteena, olemme sitä mieltä, että näiden yhteenkietoutumisten tarkastelu ja analysointi oppimisen käsittein on vasta alussa ja monin tavoin tarpeellista” (s. 15). Kirjassa tavoitellaankin artikkeleiden avulla näkökulmaa, missä rajojen ylittäminen antaisi käsitteitä uudenlaiselle työelämän o p p i m i s n ä k e m y k s e l l e . Toiviainen ja Hänninen pitävät tätä uutena keskusteluavauksena keskustelua aikaisemmin hallinneiden konstruktivismin ja organisaation oppimisen näkökulmien rinnalle.

Uudenlaisen tutkimuksellisen otteen tutkimusintressi määrittyy eri tavoin riippuen näkökulmasta, jolla ilmiötä lähestytään. Ensinnäkin tutkimuksen lähtökohdaksi voidaan ottaa tutkittava käytäntö, jolloin lähtökohdan muodostavat toimijoiden työssään kohtaamat haasteet ja näitä tutkitaan oppimisen näkökulmasta, koska oppiminen liitetään tuolloin osallistumiseen työorganisaation käytäntöihin. Toisaalta näkökulmaksi voidaan ottaa tutkijan kehittämisinterventio, jolloin oppijat muuttuvat edellisestä poiketen tietoisiksi oppijoiksi jonkin erityisen hankkeen puitteissa.

Tutkimuksen kohdekin voidaan nähdä kahden painotuksen valossa: oppimisyhteisöt ja oppimisen välineet. Jos tutkittavan kohteen painotukseksi valitaan oppimisyhteisöt, niin tällöin tutkimuksessa painotetaan vuorovaikutusta ja oppimisympäristön rakennetekijöitä sekä näiden rakenteiden ja vuorovaikutuksen rakentumista. Toisaalta kun keskitytään tutkimaan oppimisen välineitä, tällöin tutkimukselliseksi painopisteeksi asettuu jonkin erityisen työn kohde, tuotteet ja palvelut. Olennaista tällöin on tarkastella juuri näiden oppimisen välineiden käyttöönottoon ja niiden hyödyntämiseen liittyviä kysymyksiä.

\section{Neljä rajanylityksen ja oppimisen tutkimus- kenttää}

Toiviainen ja Hänninen erottelevat tutkimuksen intressin ja kohteen erittelyjen avulla neljä rajanylitysten ja oppimisen tutkimuskenttää: oppimisen evoluutiotutkimus, oppimisen kulttuurinen tutkimus, oppimisen esineellisen välittyneisyyden tutkimus ja oppimisen dialoginen tutkimus. Näiden neljän tutkimuskentän puitteisiin Toiviainen ja Hänninen tulkitsevat kirjan lukujen asettuvan kohtalaisen saumattomasti.

Oppimisen evoluutiotutkimuksessa (luvut 2 ja luku 3) tarkasteluun nostetaan laajat historialliset kehityskaaret erilaisissa innovaatioissa ja projekteissa. Oppiminen nähdään tällaisessa tutkimuksessa elimellisenä osana erilaisia yhteistyö- ja innovaatioprosesseja. Kulttuurista ulottuvuutta painottavassa tutkimuksessa (luvut 4 ja 5) tarkasteluun nostetaan yhteisöt, joissa ihmiset työskentelevät, opiskelevat ja rakentavat käytäntöjään. Oppimisen esineellisen välittyneisyyden tutkimuksessa (luvut 6 ja 7) kiinnostuksen kohteena pidetään niitä verkostoja joilla tuotetaan yhteisesti jaettua kohdetta. Se voi olla esimerkiksi tuote, palvelu tai uusi toimintatapa tai -ympäristö. Nämä verkostot ovat materiaalisesti välittyneitä erilaisina esineinä, työkaluina, teknologoina, kielenä ja merkkijärjestelminä. Oppimisen dialogisessa tutkimuksessa (luku 8) keskitytään tarkastelemaan rajanylityksiä dialogeina ja sosiaalisina vaihtosuhteina.

Kaiken kaikkiaan kirja on hyvä kokonaisesitys edellä eritellyistä teemoista. Kirja toimii hyvin oppikirjana ja tätä oppikirjamaisuutta korostaa se, että jokaiseen lukuun on liitetty lukijalle pohdintaa varten kysymyksiä ja teemoja. Kirja aukenee myös työssä oleville hyvänä väylänä, jonka avulla voi tehdä itselleen näkyväksi monia työelämässä näkymättömiin jääviä oppimisen ulottuvuuksia.

\section{Olli-Pekka Moisio}

\section{Viitteet}

1. Parviainen on toimittanut aihetta käsittelevän teoksen $\mathrm{Kol}$ lektiivinen asiantuntijuus. Tampere: UNIpress. 2005.

2. Ilmestynyt ensimmä isen kerran julkaisussa International Journal of Progressive Education 3/2006. . Artikkeli julkaistaan uudelleen teoksessa Mustafa Ynus Eryaman (ed.) Peter McLaren, Education and the Struggle for Liberation. New Jersey: Hampton Press. 2008. 